\title{
The role of export consortia in the internationalization of small and medium enterprises: A review
}

\author{
Rosa Forte, Tiago Oliveira
}

\begin{tabular}{|c|c|}
\hline & A B STRACT \\
\hline $\begin{array}{l}\text { Objective: Ex } \\
\text { larly small anc } \\
\text { overcome int } \\
\text { ternationaliza } \\
\text { fects of a con }\end{array}$ & $\begin{array}{l}\text { are a crucial strategy for the growth and survival of firms, particu- } \\
\text { dium enterprises (SMEs). However, SMEs generally lack the ability to } \\
\text { l and external export barriers and a consortium can help in their in- } \\
\text { process. So the main goals of this work are to identify the main ef- } \\
\text { um on the member firms as well as gaps in existing literature. }\end{array}$ \\
\hline $\begin{array}{l}\text { Research Des } \\
\text { mainly focus }\end{array}$ & $\begin{array}{l}\text { Methods: We resort to a review of existing empirical studies, which } \\
\text { se studies of export consortia. }\end{array}$ \\
\hline $\begin{array}{l}\text { Findings: An } \\
\text { cial, market a }\end{array}$ & $\begin{array}{l}\text { rt consortium can have effects in several firms' areas, such as finan- } \\
\text { eputational, helping them to overcome some export barriers. }\end{array}$ \\
\hline $\begin{array}{l}\text { Contribution } \\
\text { suggest that } \\
\text { account othe } \\
\text { empirical ana }\end{array}$ & $\begin{array}{l}\text { lue Added: Through the identification of literature weaknesses we } \\
\text { e research should aim to be based on larger samples and take into } \\
\text { tors that may affect exports in order to carry out a more rigorous } \\
\text { of the effects of the consortium on firms' exports. }\end{array}$ \\
\hline Article type: & research paper \\
\hline Keywords: & $\begin{array}{l}\text { internationalization; exports; consortium; strategic alliances; litera- } \\
\text { ture review }\end{array}$ \\
\hline JEL codes: & F10, F14 \\
\hline Article re & Article accepted: 12 December 2019 \\
\hline
\end{tabular}

\section{Suggested citation:}

Forte, R., \& Oliveira, T. (2019). The role of export consortia in the internationalization of small and medium enterprises: A review. International Entrepreneurship Review (previously published as International Entrepreneurship / Przedsiębiorczość Międzynarodowa), 5(4), 7-23. https://doi.org/10.15678/IER.2019.0504.01

\section{INTRODUCTION}

In an increasingly globalized economy, internationalization is presented as a key strategy to ensure growth and even the survival of firms. However, the internationalization of firms faces many obstacles, and barriers to enter foreign markets may be too large for small and medium enterprises (SMEs), forcing them to give up the internationalization (UNIDO, 2009). Most of the SMEs are confronted with a shortage of financial, production and administrative resources, and lack of knowledge and information on the potential 
export market (Leonidou, 2004). In this sense, the export consortium is presented as an alternative for SMEs to overcome the obstacles to internationalization, because its goal is "to meet the strategic intentions of the individual firms by providing business opportunities in international markets (at both regional and global levels) by overcoming the constraints that SMEs may have because of their limited size" (UNIDO, 2009, p.67). Through the promotion of networks or collaborative strategies, of which export consortia are a typical example, small and medium enterprises (SMEs) can increase their export potential (Antoldi, Cerrato, \& Depperu, 2013).

An export consortium can be defined as "a voluntary alliance of firms with the objective of promoting the goods and services of its members abroad and facilitating the export of these products through joint actions." (UNIDO, 2003, p.3). This alliance is usually a nonprofit organization that differs from other strategies of alliances because it maintains financial, legal and administrative autonomy of its members (UNIDO, 2003). Thus, as Renart (1999) report, an export consortium can be regarded as a particular type of strategic alliance. This type of organization directed to supply contrasts with the export grouping scheme that is directed to the demand. D. Welch, L. Welch, Wikinson and Young (1996) argue that this strategic alliance is created only when a specific opportunity is identified in a foreign market, while the export consortium usually focuses on finding appropriate firms, persuading them to join the group, establishing the group before making concrete international marketing research (that is, find specific market opportunities).

The objective of this study is to conduct literature review on export consortia and subsequently assessing the impact of this type of strategic alliances on its members. Literature on export consortia is relatively scarce ${ }^{1}$ and concentrated in global institutions such as UNIDO, which seek to evaluate the performance of particular cases of export consortia. In addition, part of the literature is not in English (there are several works in Spanish), making it difficult to be disseminated by the scientific community. In this way, the present work intends to explore the existing literature in order to identify weaknesses and ways of analysis for future investigations.

The structure of this paper is as follows: In Section 2 it is presented an overview of export consortia, their classification, benefits and advantages, but also its risks and disadvantages. Then, in Section 3 some case studies of international export consortia are analysed, focusing on the effects of the export consortia. Finally, we present the main conclusions and limitations, and propose lines for future research.

\section{LITERATURE REVIEW}

\section{SMEs exports barriers}

Firms, particularly small and medium enterprises (SMEs), face a number of barriers when expanding into foreign markets and an export consortium can help them to overcome some of these barriers. Leonidou (2004) classifies the barriers into internal and external barriers. As the name suggests, the internal barriers relate to internal problems of the firm, such as the lack of information on international markets and the scarcity of resources,

\footnotetext{
${ }^{1}$ In a survey carried out on the SCOPUS bibliographic database on August 3, 2017, with the keywords "export consortia" or "export consortium" or "export group", limited to the article title, only six published articles were found.
} 
while external barriers (broken down into economic barriers, and governmental / institutional barriers) derived from the macroeconomic environment, and therefore are beyond its control (Leonidou, 2004; UNIDO, 2009).

Internal barriers related to the lack of knowledge / information include lack of knowledge of foreign markets that may be associated with factors such as culture, and difficulties in identifying opportunities in foreign markets (Bilkey \& Tesar, 1977). The lack of knowledge about export assistance programs and public incentives is also considered a large internal barrier to export, particularly for SMEs (UNIDO, 2009).

Still with regard to internal barriers, another point to consider is the lack of marketing skills, causing major difficulties, such as the adoption of foreign markets requirements in terms of consumer preferences and usage conditions (UNIDO, 2003). Regarding the scarcity of resources, the main obstacles are the lack of financial resources, lack of productive capacity to commit to large orders, and lack of administrative skills / international experience of managers (Leonidou, 2004; UNIDO, 2009).

In turn, the external barriers "are those arising from uncertainties in international markets that cannot be controlled by firms since they are the result of the actions of other market players, such as governments and competitors" (UNIDO, 2009, p.8). For example, if an economy has a low degree of openness to foreign markets, firms may have to deal with protectionist policies such as tariffs on imports, which reduces the firms' competitiveness seeking to enter these foreign markets. Other examples to consider: regulatory authorities of the destination country, but also of origin, restricting the export; unfavourable economic situation; lack of assistance and government incentives for export (Leonidou, 2004; UNIDO, 2009).

\section{Types of cooperation between firms}

Before focusing our analysis on the types of consortia and their respective advantages and disadvantages, it is important to clarify the concept and address the various designations that have been adopted in the literature. Several terms have been used to refer to models of export grouped, such as strategic alliances or agreements, export consortia, export groups or "joint ventures" for export (Espejo, Fuentes, \& Núñez, 2015). Table 1 synthetizes these concepts.

Table 1. Types of cooperation between firms - definition and objectives

\begin{tabular}{|l|l|}
\hline Types of cooperation & \multicolumn{1}{c|}{ Definition/objectives } \\
\hline Strategic alliances & $\begin{array}{l}\text { "voluntary cooperative inter-firm agreements aimed at achieving competi- } \\
\text { tive advantage for the partners." (Das \& Teng, 2000, p.33) }\end{array}$ \\
\hline Export groups & $\begin{array}{l}\text { "involve a pooling of resources to support joint international research, } \\
\text { marketing and promotion activities, thereby gaining greater impact from a } \\
\text { given expenditure per company, or enabling cost reductions." (Wilkinson, } \\
\text { Young, D. Welch, \& L. Welch, 1998, p.492) }\end{array}$ \\
\hline Joint ventures & $\begin{array}{l}\text { "occurs when two or more firms pool a portion of their resources within a } \\
\text { common legal organization." (Kogut, 1988, p.319) }\end{array}$ \\
\hline Export consortia & $\begin{array}{l}\text { "A voluntary cooperation agreement between two or more companies, in } \\
\text { order to jointly develop their external markets." (Renart, 1999, p.III) }\end{array}$ \\
\hline
\end{tabular}


Strategic alliances are agreements between firms which work together to achieve a common goal. Export consortia are a particular type of strategic alliances in which its goal involves the internationalization of its members or increasing their presence on foreign markets if they have already started their internationalization (Renart, 1999). An export consortium therefore consists of a group of firms that come together to take advantage of synergies, making them more competitive, and thus reduce the costs and risks of internationalization (The Latin American and Caribbean Economic System [SELA], 2015).

As highlighted by Antoldi et al. (2013), an export consortium can be classified as an "horizontal" network. This type of network is defined by Ghauri, Lutz and Tesfom (2003) as cooperative relationship between firms seeking to solve a common problem of marketing, increase production efficiency, or take advantage of a market opportunity by mobilizing and sharing resources. The establishment of horizontal links with other domestic partners can help firms to solve various kinds of problems they face to start the export process, including those related to the quality of the value proposition, organizational and financial issues, and the lack of information in relation to foreign markets (Antoldi et al., 2013).

\section{Types of export consortia}

The export consortia classification is vast, ranging from author to author. An export consortia can be classified taking into account several factors, but, according to UNIDO (2009), objectives and scope are probably the most common. Based on the objectives and scope, the main types of export consortium are the promotional and sales consortia (Renart, 1999; UNIDO, 2003).

A promotional consortium is an alliance created to explore international markets, helping members to enter these markets and promoting their products (e.g. in international fairs), sharing the costs of these actions (UNIDO, 2009). The structure of this type of consortium is "lighter" than the sales consortium, in which the goal is to sell the products of the members in foreign markets and promote business activities, unlike the promotional consortium where sales are made directly by the member firms. As highlighted by UNIDO (2009) "Promotional consortia invest their financial and human resources in marketing, whereas sales consortia act as a distribution channel and have to invest more in order to set up a sales organisation" (p.19).

According to UNIDO (2003), Antoldi, Cerrato and Depperu (2011), and Espejo et al. (2015), an export consortia can also be classified by the following factors (among others): sector to which they belong (if member firms are part of the same sector or not - mono sectoral and multisector, respectively); type of relationship between firms (vertical or horizontal); members location (regional or multi-regional). Furthermore, it may also be taken into account if the goods produced by the consortium members are complementary or if goods are substitutes competing among themselves, ${ }^{2}$ the consortium duration and complexity.

In terms of complexity, there are several export consortia categories, from the simplest, which provides only secretariat functions and assists in communication and translation between agents, until those who assume the responsibility of sales and marketing

\footnotetext{
${ }^{2}$ For example, according to Criado, Carazo and Criado (2005), the Spanish consortium COFME is an uni-sectorial (electrical equipment) export consortium despite the member firms belong to other subsectors (such as tools, emergency lighting, sound and internal communication systems, etc.). Since the members produce different electrical materials, their products are complementary not competing with each other for customer preference.
} 
departments of the consortium members having a significant administrative autonomy (UNIDO, 2003). According to UNIDO (2003), the newly created consortia should not be from the beginning too sophisticated. It is therefore advisable that there is an incremental evolution and development of the export consortium. This progression should occur as relations between its members strengthen and the cohesion of the group consolidates. Despite the usual be the identification of consortia by commercial activity, all factors must be taken into consideration for a strategic analysis of the consortium, and understand what features may represent a threat or a weakness, an opportunity or a competitive advantage (UNIDO, 2009).

Whatever the type of export consortium, the members must recognize and value the potential gains from joint efforts so that cooperation between them to develop. For the success of the alliance is essential that the perceived benefits by its members outweigh the costs and contributions made by these (Wilkinson et al., 1998). Thus, in the following sections we summarize the main benefits and the main disadvantages of export consortia.

\section{Benefits of an export consortium}

The recognition of several benefits that can be obtained through an export consortium is very important to strengthen the desire of the members to participate and cooperate. According to UNIDO (2009) who studied nine cases of consortia, firms can obtain several benefits from cooperating in an export consortium, such as accumulation of knowledge, cost sharing, obtaining public support, among others, which resulted in an increase of exports and turnover of its members. Table 2 presents a summary of the advantages of export consortium in relation to other types of strategic alliances, and its potential benefits.

As stated by UNIDO (2003), the firms in the consortium maintain a high degree of independence, maintaining their financial, legal and administrative autonomy, which makes this type of alliance suitable for small and medium enterprises (SMEs) wishing to work together to achieve the same goal, without having to lose or get very limited in decision-making. According to SELA (2015) "The consortium is not the unification of the companies integrating it, since they simply participate in the creation of a new organization with which they establish a trade agreement" (p.22). These characteristics inherent to the export consortium are also very useful at the time of dissolution of the alliance or when one of the firms intends to leave the consortium. Whatever the reason for the dissolution / exit, such as the willingness to individually pursue their international activities or the failure to achieve the proposed objectives, the fact that the structure of an export consortium is more flexible and lighter than other types of strategic alliances allows that firms are able to leave the consortium easily, without any constraints or high sunk costs (Silva \& Sousa, 2009; UNIDO, 2003). Furthermore, firms "can continue trading other products individually on other markets" (SELA, 2015, p.21).

The maintenance of autonomy at various levels is the great advantage of export consortia in relation to other types of strategic alliance, such as joint ventures. Additionally, the investment involved is smaller, there is less risk and less restrictions (Antoldi et al., 2011; Bigliardi et al., 2011). However, according to Antoldi et al. (2011), the lowest risk and involvement can lead to consortium members to strive less than they should and therefore the results of the consortium may be lower than planned. This may lead to a vicious circle, because the failure will cause firms do not feel motivated to strive, causing, ultimately, the failure of the consortium. 
Table 2. Advantages of an export consortium compared to other strategic alliances and export consortia benefits

\begin{tabular}{|c|c|c|c|}
\hline $\begin{array}{l}\text { Advantages of an export consor- } \\
\text { tium in relation to other types of } \\
\text { strategic alliances }\end{array}$ & Author (year) & $\begin{array}{l}\text { Benefits of export } \\
\text { consortium }\end{array}$ & Author (year) \\
\hline $\begin{array}{l}\text { High degree of independence of } \\
\text { the members }\end{array}$ & \multirow{3}{*}{$\begin{array}{l}\text { SELA (2015); } \\
\text { UNIDO (2003) }\end{array}$} & $\begin{array}{l}\text { Reduction of internal and ex- } \\
\text { ternal barriers to internation- } \\
\text { alization }\end{array}$ & $\begin{array}{l}\text { Leonidou } \\
(2004) ; \text { UNIDO } \\
(2009)\end{array}$ \\
\hline Greater flexibility & & $\begin{array}{l}\text { Expansion of business con- } \\
\text { tacts network }\end{array}$ & UNIDO (2009) \\
\hline $\begin{array}{l}\text { Financial, legal and administrative } \\
\text { autonomy }\end{array}$ & & \begin{tabular}{|l} 
Acquisition of knowledge and \\
sharing of experiences
\end{tabular} & $\begin{array}{l}\text { SELA (2015); } \\
\text { UNIDO (2003) }\end{array}$ \\
\hline Lower risk & $\begin{array}{l}\text { Antoldi et al. } \\
\text { (2011); Bigliardi, } \\
\text { Dormio and } \\
\text { Galati (2011) }\end{array}$ & Economies of scale & $\begin{array}{l}\text { Bigliardi et al. } \\
\text { (2011); UNIDO } \\
(2009)\end{array}$ \\
\hline Easy dissolution or abandonment & $\begin{array}{l}\text { Silva and Sousa } \\
\text { (2009); UNIDO } \\
(2003)\end{array}$ & $\begin{array}{l}\text { Easier to get support from } \\
\text { public entities } \\
\text { Sharing of costs and risks re- } \\
\text { lated to internationalization } \\
\text { Greater bargaining power }\end{array}$ & $\begin{array}{l}\text { Antoldi et al. } \\
\text { (2011); Renart } \\
\text { (1995); Renart } \\
\text { (1999) }\end{array}$ \\
\hline $\begin{array}{l}\text { Position to pursue, at the same } \\
\text { time, international activities indi- } \\
\text { vidually }\end{array}$ & \multirow{2}{*}{$\begin{array}{l}\text { Antoldi et al. } \\
(2011) ; \text { SELA } \\
(2015)\end{array}$} & $\begin{array}{l}\text { Joint participation in interna- } \\
\text { tional fairs and missions } \\
\text { Ability to create own brand } \\
\text { representative of the consor- } \\
\text { tium }\end{array}$ & \multirow[b]{2}{*}{ UNIDO (2009) } \\
\hline Lower investment & & $\begin{array}{l}\text { Wider range of products if the } \\
\text { consortium members have } \\
\text { complementary products } \\
\text { More responsive to large or- } \\
\text { ders if members produce sim- } \\
\text { ilar products }\end{array}$ & \\
\hline
\end{tabular}

Source: own elaboration based on the literature reviewed.

In addition to the aforementioned advantages, it is noteworthy that an export consortium presents other potential benefits. It may arise connections between members resulting from the activities carried out by the consortium, which can improve their competitiveness (Antoldi et al., 2011; SELA, 2015). Furthermore, the export consortium allows exploit economies of scale without losing flexibility and represents a solution to overcome the internal and external barriers to internationalization that members individually do not have the expertise and resources to overcome (UNIDO, 2009). This benefit is one of the main advantages of belonging to a consortium and is regarded as one of the main reasons for creating this type of strategic alliance.

Participation in an export consortium can help to overcome some export barriers (e.g. lack of knowledge / information about foreign markets) by allowing firms to increase their knowledge of the markets (SELA, 2015). As highlighted by SELA (2015) "They obtain more information regarding the markets where they will participate and 
they prepare better to satisfy the demands of these markets" (p.21). Moreover, as reported by UNIDO (2003), the acquisition of knowledge resulting from the sharing of information and experiences of the consortium members is a solution to combat internal barriers related to the lack of marketing skills, which can be extended to other areas such as negotiating with banks or to implement certain standards required internationally, as the members are aware of the benefits of cooperation between firms. In short, one of the main advantages of the export consortium is to provide specialized management, marketing skills, as well as facilitate access to acquisition / adoption of trademarks and patents to the members of the alliance (Bigliardi et al., 2011).

Furthermore, an export consortium can help to overcome barriers related to the scarcity of resources, combining resources and efforts, benefiting from economies of scale, obtaining a wider range of products, improving and intensifying promotional activities abroad, such as the skills of staff and administrative managers (UNIDO, 2009).

Taking into account the collective nature of the consortium, public / private agencies become more efficient than if they had to assist each firm individually, because they have only to deal with an organization, making it easier to get this public support to internationalization (Antoldi et al., 2011), which help to overcome some external export barriers mentioned above.

The advantages / disadvantages are also related to the type of export consortium (promotional versus sales). For example, the potential of promotional consortia to explore economies of scale is much lower than the second type of consortium (UNIDO, 2009). Promotional consortia can only benefit in terms of cost sharing (such as cost from participation in fairs), while sales export consortia can provide gains in several areas, from the distribution channels to the sales department.

Another advantage of the export consortium related to public agents has to do with subsidies these agents assign in order to promote the consortia, which can reach on average $35-40 \%$ of costs and investments of the group in the early years of the alliance (Renart, 1995). The author stresses that it is still possible to get more public financial support, in order to promote exports and the internationalization of the firms which may result from the consortium. The same author (Renart, 1995) also notes that with these new financial resources, and the sharing of internationalization costs for all members of the export consortium, it may be more prone to hire a competent expert in the field of internationalization and export, which may prove to be an important asset, and thus contribute to the success of the organization.

An export consortium can also contribute to risk reduction and improvement in profitability. The risk reduction can be accomplished through the increased knowledge obtained about a market and a greater diversification of target export markets (UNIDO, 2003). The improvement in profitability can be achieved both in terms of costs reduction (for example, the sharing of administrative and advertising costs) and in terms of revenues, increasing total sales by international customers (UNIDO, 2003). SELA (2015) also emphasise the reduction of costs ("distribution of expenses among the different partners") as an important advantage of the export consortium.

Still related to improved profitability in the cost side, the cooperation of member firms may result in greater bargaining power over its suppliers and agents of the distribution channels, resulting in a decrease in spending in these business areas (Renart, 1995). Also SELA 
(2015) highlights that the participation in export consortia enables firms to increase their ability to negotiate with foreign agents, such as distributors, importers and customers.

Despite the various benefits that can be obtained from cooperation and the presence in an export consortium, it also carries risks and has disadvantages, which should be taken into consideration in the creation and management of the export consortium.

\section{Risks and disadvantages of export consortia}

The disadvantages and risks of participating in an export consortium should be analyzed and studied when it is created in order to take preventive measures to minimize their negative impacts (Renart, 1995). According to UNIDO (2009), this type of alliance has risks since the evidence shows that usually firms only get concrete results two years after the creation of the consortium which may cause a decrease in the effort by the consortium members, for thinking that the alliance is a failure and, consequently, can actually compromise the success of the export consortium. These risks and disadvantages are summarized in Table 3. The table is divided into three parts: the first refers to the risks and disadvantages of all types of export consortia; the second refers only to the risks and disadvantages of promotional consortia; the latter refers to sales consortia.

As with all types of strategic alliances, there are several factors that can create problems in the export consortium and jeopardize the success of the union. These factors are due largely to the nature of its members and the interactions between them. According to Antoldi et al. (2011), the difference in size between the members may be the source of many problems which, ultimately, can lead to at least one member leaves the organization. In the case of a firm to be considerably smaller than the others, it may not have the necessary resources to contribute with its share. If the remaining members did not consider their contribution enough, it is likely that the result is the abandonment of the consortium by the smaller firm. In the opposite case, the firm with greater size can bias the balance of power between members and have too much influence in the decisions taken by the group, or being too ambitious with its internationalization objectives, which can also lead to misunderstandings and disagreements in the alliance.

Summing up, "Differences in size can be an obstacle to formulating strategy because different visions and goals can be size-related, and different sizes lead to differences in terms of availability of resources" (UNIDO, 2009, p. 76).

Cultural differences should also not be underestimated, since they can hamper the strategic planning of the export consortium. Organizational culture is affected by several factors such as business models, beliefs, values, industry in which it operates and nationality, and in the case of SMEs their cultural identity is strongly influenced by their leaders (Antoldi et al., 2011; Renart, 1999; UNIDO, 2009). Thus, the management of relationships between entrepreneurs and leaders of the firms participating in an export consortium is vital to the success of the consortium, being necessary to foster the relationship among members. Thus, informal activities to create trust and sympathy, are fundamental so that cooperation develops (UNIDO, 2003).

To Renart (1999), a problem that over time can arise in the export consortium concerns the earnings disparities obtained by different members of the organization, including business results and knowledge acquired, which, according to the author, occur frequently and may generate tensions between the member firms. Firms in trying to justify this discrepancy may think that this difference is due to the fact that the executive director 
of the consortium is biased, giving preferential treatment to certain firms. Additionally, this may require a change in the contributions made by alliance members (Renart, 1999; UNIDO 2003). Another problem are the "hidden agendas", i.e., certain member firms may be hiding the true goals (different from those stated) (Antoldi et al., 2011; UNIDO, 2003; UNIDO, 2009). These authors show that there are several reasons why firms have hidden agendas, for example, obtaining an advantage over another firm or not share important information in order to gain a competitive advantage over partners. In addition, there is the possibility of a firm plans to join the export consortium without any genuine intention to cooperate and its interest in obtaining the benefits to be placed in the background, aiming only to get an opportunity to spy on other firms, or simply due to a direct rival entered the strategic alliance (Antoldi et al., 2011; UNIDO, 2003; UNIDO, 2009).

Table 3. Risks and disadvantages of export consortia

\begin{tabular}{|c|c|c|}
\hline \multicolumn{2}{|c|}{ Risks and disadvantages of export consortia } & \multirow{2}{*}{\begin{tabular}{|l|} 
Author (year) \\
Antoldi et al. (2011); UNIDO \\
(2009)
\end{tabular}} \\
\hline \multirow{10}{*}{$\begin{array}{l}\text { Export } \\
\text { consortia }\end{array}$} & $\begin{array}{l}\text { Size differences between members which makes it } \\
\text { difficult to define the strategy }\end{array}$ & \\
\hline & Cultural diferences & Renart (1999) \\
\hline & Disparities in gains obtained & Renart (1999); UNIDO (2003) \\
\hline & Secret diaries & $\begin{array}{l}\text { Antoldi et al. (2011); UNIDO } \\
\text { (2005); UNIDO (2009) }\end{array}$ \\
\hline & $\begin{array}{l}\text { Lack of cooperative spirit and reluctance to work } \\
\text { jointly }\end{array}$ & $\begin{array}{l}\text { Bigliardi et al. (2011); UNIDO } \\
\text { (2009); Welch et al. (1996) }\end{array}$ \\
\hline & Too large dependence on external agents & $\begin{array}{l}\text { UNIDO (2009); Welch et al. } \\
\text { (1996) }\end{array}$ \\
\hline & \begin{tabular}{|l|l} 
Little effort / dedication \\
\end{tabular} & Antoldi et al. (2011) \\
\hline & $\begin{array}{l}\text { Difficulties in drafting the statutes, contracts and so- } \\
\text { cial pacts and their review }\end{array}$ & Renart (1999) \\
\hline & "Free-riding" & Brito \& Silva (2005) \\
\hline & Divergent views on goals and targets & \multirow{4}{*}{ UNIDO (2009) } \\
\hline \multirow{3}{*}{$\begin{array}{l}\text { Promotional } \\
\text { consortium }\end{array}$} & $\begin{array}{l}\text { Inconsistency between the image and the prices of } \\
\text { its products }\end{array}$ & \\
\hline & Perception of the gains obtained by the consortium & \\
\hline & Limited economies of scale gains & \\
\hline \multirow{4}{*}{$\begin{array}{l}\text { Sales } \\
\text { consortium }\end{array}$} & $\begin{array}{l}\text { Poor quality of at least one of the organization's } \\
\text { members }\end{array}$ & \multirow{4}{*}{ Antoldi et al. (2011) } \\
\hline & $\begin{array}{l}\text { Table of prices charged inconsistent with the alliance } \\
\text { value proposition }\end{array}$ & \\
\hline & $\begin{array}{l}\text { Little variety of products when the consortium has } \\
\text { complementary businesses; }\end{array}$ & \\
\hline & $\begin{array}{l}\text { Reduced ability to respond to large orders of the } \\
\text { same product if the consortium has too heterogene- } \\
\text { ous members. }\end{array}$ & \\
\hline
\end{tabular}

Source: own elaboration based on the literature reviewed.

Additionally, according to Bigliardi et al. (2011), firms are reluctant to actively participate in a consortium because they see it as a way to lose control over the decision making of their firms, and are afraid that a strategic alliance allows potential rivals easy access to their local markets. 
The export consortium is not a risk-free strategy as evidenced above, since, in addition to the described problems, there are others, such as incompatible business models, difficulty in putting firms to work together effectively, too high dependence on agents external to the export consortium (such as public institutions) to support strategic alliances (UNIDO 2009;. Welch et al., 1996), so it is always needed good management and monitoring of this strategic alliance.

According to Welch et al. (1996) and UNIDO (2003), most of these risks can be managed or prevented with careful analysis in the process of selection of firms that are part of the strategic alliance and with the promotion of relations and solidarity between members, making it clear in all export consortium steps the gains the firms can by integrating the consortium, in order not to encourage deviant attitudes.

In addition to the risks inherent to the export consortium, it should be noted that this also has disadvantages compared to other types of strategic alliances and difficulties that must be managed. One of the biggest difficulties of this type of alliance is to identify common goals and to define a strategy to achieve those goals (UNIDO, 2009). In this regard, export grouping scheme which, as mentioned above, is formed only when a specific opportunity is located in a foreign market, have an advantage compared to the export consortium, because they are set clear objectives from the outset, which minimizes the concerns of potential members on the benefits that this strategic alliance may provide (Wilkinson et al., 1998). However, the first type of alliance has the disadvantage of requiring a study on an international opportunity that firms can take advantage, what is costly and takes time. Typically, this analysis is done by public agencies in order to promote exports and national competitiveness (Wilkinson et al., 1998).

Despite the lower investment required to achieve an export consortium, and its flexibility (compared to other forms of cooperation) be considered an important advantage over other types of cooperative organizations, consortium members may neglect to the extent that they have little to lose, a situation that can lead them to strive less than they should. Consequently, the consortium's results may be lower than planned (Antoldi et al., 2011).

In addition, and also related to the consortium flexibility, difficulties may arise in the drafting of laws, contracts or social pacts, to the extent that firms do not want to get too involved (Renart, 1999). According to the same author, the revision of the statutes can also present itself as a major obstacle because, in the event of unforeseen situations (macro-economic changes or circumstances that were not foreseen at the beginning of the export consortium) which require amendments to the Statutes, member firms may not be willing to do so, creating conflicts within the strategic alliance.

Another disadvantage in strategic alliances is the "free-riding", that is the existence of alliance members that do not participate in joint actions because they prefer to benefit from the efforts of others, without having to spend any financial resources (Brito \& Silva, 2005). This occurrence may create conflicts both in the short and long term, and tensions between individual interests and collective interests. This problem differs from the problem of hidden agendas because in the latter case, as explained above, there is no interest in obtaining the benefits to which the alliance was created, unlike what happens in the "free-riding" in that there is such interest, but it is not intended to contribute or cooperate for the success of the organization. This is prone to happen if the financing system of the export consortium is not 
fair and well planned; in addition the determination of the contributions to the funds of the strategic alliance may generate, by itself, conflicts and tensions (Renart, 1999).

Thus, in order to avoid conflicts, the contributions of the export consortium members should have two components: an annual / monthly fixed quota for all members in order to avoid the "free-riding"; special contributions for specific services or actions, in order to avoid large disparities between the earnings of the consortium members. Another benefit of this second component would be to present to the members the option to participate or not in a joint action, without having to bear costs for something that they have not benefited (UNIDO, 2003).

In addition, the promotional consortium may face difficulties such as inconsistency between the image and the prices of their products, the perception of the gains obtained by the consortium and different opinions on which goals and objectives the organization must continue, geographically and target markets (UNIDO, 2009). Moreover, the weaknesses / disadvantages of sales consortium are: poor quality of at least one member of the organization affecting negatively the image of the others; list of prices practiced inconsistent with the value proposition of the alliance; poor variety of products if the consortium does not include complementary firms; absence of skills related to sales (Antoldi et al., 2011).

In conclusion, considering the advantages and disadvantages of the export consortium, this type of alliance presents itself as a viable solution for the internationalization of small and medium enterprises, and according to Antoldi et al. (2011) its biggest advantages compensate typical weaknesses. Ideally, an export consortium should establish clear goals after selecting the potential members. According to UNIDO (2003) "participating firms must meet carefully defined criteria with respect to their size, reputation, financial stability and the goods or services they offer. They must be able to offer products of adequate quality, in sufficient volumes and at a price that is competitive at the international level" (p.23).

\section{MATERIAL AND METHODS}

Export consortia have been used in several countries in order to assist firms in their internationalization process. In this section we analyse some cases of export consortia, seeking to ascertain whether they have achieved the objectives that are proposed on its creation. The presented case studies cover several sectors and countries across three continents (Europe, Africa and South America). Table 4 presents a summary of the information regarding to 13 international export consortia, focusing on the designation of the consortium and the respective year of establishment, the country, the sector of activity, the number of members and type of consortium, as well as the main benefits, particularly in terms of impact on exports, turnover, bargaining power, among others.

Observing Table 4 we can see that only two consortia are in developed countries (Spain and Italy), seven of them are from South America, and the rest (four) from the North Africa. There are several sectors covered by these alliances, although the agricultural and food sector is represented in greater number.

Regarding the number of members in most consortia it is within normal parameters for a consortium. According to Renart (1995), typically they have between three to seven members. According to UNIDO (2003), the number of firms belonging to the strategic alliance varies greatly depending on their objectives and size of the members. The consortium must 
be large enough in order to obtain the necessary resources for an adequate supply of services to achieve the goals that individual firms cannot reach, but the cohesion and efficiency of the group decreases as the size of the strategic alliance increases (UNIDO, 2003).

Concerning the type of consortium it appears that most usual are promotional export consortia, and only three are a sales consortia. It is possible that some of these evolve into a sales consortium, as the alliance develops and the reluctance of firms to give up part of their autonomy decreases as opposed to the potential benefits.

Considering that one of the main objectives of these strategic alliances is to export, only four of the thirteen consortia of Table 4 do not present data for exports. The lack of such information does not mean that the consortium had no impact on exports of its members. With regard to the consortia that provide information, it can be seen that exports have a strong increase. In the case of promotional consortia, as mentioned before, it is particularly difficult to analyse the performance of this type of consortia to the extent that they apply their resources in promoting the products of their members, and the firms are responsible for their sales. As a result, sales will not be awarded to the consortium because they are registered by the members themselves (UNIDO, 2009).

Benefits such as increasing the number of contacts, the acquisition of knowledge and greater bargaining power were in general also observed in most cases, showing that an export consortium can bring advantages to be taken into account, although they are not directly measurable or they are difficult to assess.

In addition to the benefits and advantages presented in Table 4, it is noted that there were other benefits and advantages disclosed in the case studies of export consortia. In most cases, the creation of the strategic alliance allowed the joint participation in international fairs and missions, which provided an opportunity to establish new relationships and create a positive image of the export consortium at the international level. Piñero et al. (2011) present a case of a promotional export consortium, GAPMA, an Argentine consortium in which their first joint activities were related to the creation of an identity for the group and then to promote their products through trade missions and international fairs. On the other hand, according to Criado et al. (2005) the Spanish export consortium, COFME, is a sales consortium created in 1998 and its first activities were related to collective purchases from suppliers and joint negotiations with commercial agents (e.g. transport firms), with the objective of making gains through greater bargaining power. As it was developing this organization created a sales department and in 2008 it had 13 selling platforms in international markets.

In addition, as evidenced in the various sources of Table 4, the creation of an entity with larger size made it easier to obtain public and private funding such as export promotion agencies or consultancy firms. Another benefit resulting from the consortia work was to obtain quality certificates of members' products of the three export consortia (COFME, Vitargan and Phyto Uruguay) and to obtain, by the Italian consortium (Parma), product recognition of certified origin. This quality recognition from international organizations has contributed to a greater internationalization of the members of the export consortia (Criado et al., 2005; O'Reilly et al., 2003; UNIDO, 2009).

In the cases studied by UNIDO (2009), it was analysed the evolution of firms skills in order to ascertain to what extent those skills have improved by participation in in the export consortium. According to data obtained by this organization, in general, firms belonging 
Table 4. Synthesis of export consortium cases - characteristics and effects

\begin{tabular}{|c|c|c|c|c|c|c|c|c|c|c|c|c|}
\hline \multirow[b]{2}{*}{ Case studies } & \multicolumn{4}{|c|}{ Consortium characteristics } & \multicolumn{7}{|c|}{ Consortium effects } & \multirow[b]{2}{*}{ Source } \\
\hline & Country & Sector & $\begin{array}{l}\text { № of } \\
\text { firms }\end{array}$ & $\begin{array}{c}\text { Type of } \\
\text { consortium }\end{array}$ & Exports & Turnover & $\begin{array}{c}\text { № of } \\
\text { Business } \\
\text { Contacts / } \\
\text { Customers }\end{array}$ & Knowledge & Costs & $\begin{array}{c}\text { Bargaining } \\
\text { power }\end{array}$ & $\begin{array}{c}\text { Foreign } \\
\text { presence }\end{array}$ & \\
\hline $\begin{array}{c}\text { Brazilian Health } \\
\text { Products } \\
\text { (2002)* }\end{array}$ & Brazil & $\begin{array}{l}\text { Health } \\
\text { products }\end{array}$ & 12 & Promotional & $\uparrow 268,2 \%$ & 个 $43,2 \%$ & & $\begin{array}{l}\text { Foreign trade } \\
\text { and marketing }\end{array}$ & $\downarrow$ & $\uparrow$ & & $\begin{array}{l}\text { Lima, Garcia , de } \\
\text { Carvalho and } \\
\text { Martinelli (2007) }\end{array}$ \\
\hline GAPMA (2003) & Argentina & $\begin{array}{l}\text { Agriculture } \\
\text { machinery }\end{array}$ & 12 & Promotional & $\begin{array}{c}\uparrow \text { About } \\
60 \% \text { per year }\end{array}$ & & $\uparrow$ & $\begin{array}{c}\text { Sharing } \\
\text { experiences }\end{array}$ & $\downarrow$ & & $\begin{array}{l}\text { Higher } \\
\text { visibility }\end{array}$ & $\begin{array}{c}\text { Piñero, Herrera } \\
\text { and Di Meglio } \\
\text { (2011) }\end{array}$ \\
\hline COFME (1998) & Spain & $\begin{array}{l}\text { Electric } \\
\text { material }\end{array}$ & 7 & Sa les & $\begin{array}{l}\text { Increased } \\
\text { share of } \\
\text { total sales }\end{array}$ & $\uparrow$ & & $\begin{array}{c}\text { Sharing } \\
\text { information }\end{array}$ & $\downarrow$ & $\uparrow$ & $\begin{array}{l}\text { About one } \\
\text { hundred } \\
\text { countries }\end{array}$ & $\begin{array}{l}\text { Criado et al. } \\
\text { (2005) }\end{array}$ \\
\hline Mosaic (2004) & Morocco & Textile & 6 & Promotional & $\begin{array}{l}\text { 个 } 30 \% \text { on } \\
\text { average }\end{array}$ & & $\uparrow$ & $\begin{array}{l}\text { Acquisition of } \\
\text { knowledge } \\
\text { about markets }\end{array}$ & & $\uparrow$ & $\begin{array}{c}\text { Better } \\
\text { positioning }\end{array}$ & \\
\hline Vitargan (2005) & Morocco & Agriculture & 6 & Promotional & & & $\begin{array}{c}\text { Slight } \\
\text { increase }\end{array}$ & $\begin{array}{c}\text { Acquisition of } \\
\text { knowledge }\end{array}$ & $\downarrow$ & $\uparrow$ & \begin{tabular}{|c|} 
Higher \\
reputation \\
and visibility
\end{tabular} & \\
\hline $\begin{array}{c}\text { Travel Partners } \\
(2006)\end{array}$ & Morocco & Tourism & 7 & Promotional & & & $\begin{array}{c}\text { Slight } \\
\text { increase }\end{array}$ & $\begin{array}{c}\text { Knowledge } \\
\text { about markets }\end{array}$ & $\downarrow$ & $\uparrow$ & $\begin{array}{c}\text { Access to } \\
\text { new markets }\end{array}$ & \\
\hline Get'IT (2005) & Tunisia & $\begin{array}{l}\text { Information } \\
\text { technology }\end{array}$ & 6 & Promotional & & $\begin{array}{c}\text { 个 About } \\
30 \%\end{array}$ & $\uparrow$ & $\begin{array}{c}\text { Knowledge } \\
\text { about markets }\end{array}$ & & & \begin{tabular}{|c|} 
Greater \\
visibility and \\
reputation
\end{tabular} & \\
\hline Muyu (2005) & Peru & $\begin{array}{l}\text { Handmade } \\
\text { products }\end{array}$ & 5 & Promotional & 个 $235 \%$ & $\uparrow 100 \%$ & $\begin{array}{c}\text { Slight } \\
\text { increase }\end{array}$ & $\begin{array}{c}\text { Knowledge } \\
\text { about markets }\end{array}$ & & & $\begin{array}{c}\text { Greater } \\
\text { visibility and } \\
\text { reputation }\end{array}$ & UNIDO (2009) \\
\hline $\begin{array}{c}\text { Peruvian Bio } \\
\text { Consortia } \\
\text { (2006) }\end{array}$ & Peru & $\begin{array}{l}\text { Natural } \\
\text { products }\end{array}$ & 3 & Promotional & $\begin{array}{c}\text { 个About } \\
40 \%\end{array}$ & 个 $20 \%$ & $\begin{array}{c}\text { Slight } \\
\text { increase }\end{array}$ & & & & $\begin{array}{c}\text { Image } \\
\text { enhancement }\end{array}$ & \\
\hline ACMC (2007) & Peru & $\begin{array}{c}\text { Metal and } \\
\text { engineering }\end{array}$ & 4 & Sales & $\uparrow 205,5 \%$ & 个 $95,5 \%$ & $\begin{array}{c}\text { Slight } \\
\text { increase }\end{array}$ & & & & & \\
\hline $\begin{array}{l}\text { Ande Natura } \\
\text { (2007) }\end{array}$ & Peru & $\begin{array}{c}\text { Organic } \\
\text { food }\end{array}$ & 5 & Promotional & 个 $384,5 \%$ & $\begin{array}{c}\text { 个 About } \\
85 \%\end{array}$ & $\uparrow$ & $\begin{array}{c}\text { Sharing of } \\
\text { information } \\
\text { among } \\
\text { members }\end{array}$ & $\downarrow$ & & $\begin{array}{c}\text { Increased } \\
\text { promotional } \\
\text { activities }\end{array}$ & \\
\hline \begin{tabular}{|c|} 
Phyto Uruguay \\
(2005)
\end{tabular} & Uruguay & Food & 9 & Sales & & 个 $20 \%$ & & $\begin{array}{c}\text { Sharing } \\
\text { experiences }\end{array}$ & & $\uparrow$ & & \\
\hline Parma (1963) & Italy & Food & 23 & Promotional & $\begin{array}{c}€ 237 \\
\text { Millions }\end{array}$ & 个 $15 \%$ & $\uparrow$ & $\begin{array}{c}\text { Access to } \\
\text { information }\end{array}$ & & & $\begin{array}{l}\text { About } 80 \\
\text { countries }\end{array}$ & $\begin{array}{l}\text { O'Reilly, Haines } \\
\text { and Arfini (2003) }\end{array}$ \\
\hline
\end{tabular}

Legend: $\uparrow$ - Significant increase; $\downarrow$ - Significant decrease; *- Consortium dissolved in 2005

Source: own elaboration based on the literature reviewed. 
to the consortium improved their technical, administrative, and marketing skills and their capacity of analysing international markets.

In terms of the consortium duration, according to Renart (1995), its duration is not defined or limited in advance. However, in most cases the participation of a firm in an export consortium is a phenomenon of limited duration in time. When firms acquire the knowledge and skills to export autonomously they may leave the consortium and it can be dissolved (Renart, 1995).

In the case study of Lima et al. (2007) the export consortium was dissolved three years after its creation, in 2005, but this does not mean that the organization has failed. According to the authors this alliance ended because the main mission of the consortium (to help firms to enter foreign markets) had been fulfilled to the extent that the firms integrating the consortium had already started their activities in international markets, obtained knowledge about these markets, and were already able to export individually. This facility to finish the export consortium when the members of the organization desire is another advantage compared to other types of strategic alliances, which present great difficulties and obstacles to its end (UNIDO, 2003).

However, despite the success of the cases presented, in the case of the "Parma" consortium it was identified some problems that may arise in the development of a strategic alliance. Despite the creation of a single brand to be a differentiating factor from other competitors' products, the members of "Parma" have difficulties in creating their own brand due to the domain of the unique brand. Consequently, some members decided to undertake their own advertising and avoid generic promotion that would benefit all members (O'Reilly et al., 2003).

O'Reilly et al. (2003) also highlighted another problem, which was the debate between the produced volume of hams versus a premium price. The dramatic increase of consortium members (from 23 to 201) led to increased production, thus pushing prices to lower. Since Parma ham is a high quality product, this should have a high price, a situation that the consortium could not control because of the enormous quantity produced with the trademark "Parma" and the difficulty in flow the production of the members of this alliance (O'Reilly et al., 2003).

An informal network of cooperation between firms is not uncommon. The existence of informal relationships between firms can help to overcome barriers such as mistrust and help solidify mutual aid within the consortium. According to Marschan et al. (1996) and Turnbull (1990) "personal, informal relations among people at various levels of an organization play a key role in developing the relationship and providing a foundation for mutually beneficial cooperation between firms"(as cited in Welch et al., 1996, p. 475).

To sum up, an export consortium can have effects in six areas, as evidenced in Table 5.

\section{CONCLUSIONS}

This study aimed to carry out a literature review on the topic of SMEs export consortia. This type of alliance can be a viable approach to overcome internal and external barriers to export and thereby benefit SMEs helping them in their internationalization process. 
Table 5. Synthesis of the consortia effects on firms' areas

\begin{tabular}{|l|l|}
\hline \multicolumn{1}{|c|}{ Areas } & \multicolumn{1}{c|}{ Consortia effects } \\
\hline Financial & $\begin{array}{l}\text { Improvement of financial results, such as the return on assets or the return on } \\
\text { sales, because the greater bargaining power derived from joint purchases allows } \\
\text { member firms lower purchasing costs. }\end{array}$ \\
\hline Market & $\begin{array}{l}\text { Growth of exports and number of markets supplied; greater notoriety in the do- } \\
\text { mestic market. }\end{array}$ \\
\hline Learning & $\begin{array}{l}\text { Acquirement and expansion of "knowledge-based resources and competencies } \\
\text { from and with the other partners" which facilitate the approach to new markets. }\end{array}$ \\
\hline Reputational & $\begin{array}{l}\text { Greater recognition of the members' brand as well as of the consortium, which is } \\
\text { especially important for promotional consortia. }\end{array}$ \\
\hline Innovation & $\begin{array}{l}\text { Acquisition of relevant feedback for updating and innovating the range of prod- } \\
\text { ucts / services. }\end{array}$ \\
\hline Relational & $\begin{array}{l}\text { Assistance in the development of new business contacts, both domestically and } \\
\text { abroad. }\end{array}$ \\
\hline
\end{tabular}

Source: adapted from UNIDO (2009, p.113).

Among the various benefits of the consortium, the literature highlights the increased presence in foreign markets reflecting an increase in exports, increased business contacts, increased bargaining power, and acquisition of knowledge about markets, among others. The review of papers focusing on the study of consortium cases corroborates the benefits identified. In particular, it can be seen that the internal competences of the member firms related to internationalization, such as number of clients abroad and the positioning in the international market, have improved significantly.

The present literature review allowed us to conclude that the existing studies have focused mainly on the analysis of export consortia in developing countries. To our knowledge, only Criado et al. (2005) and O'Reilly et al. (2003) focus on cases of consortia from developed countries as is the case of Spain and Italy, respectively. In addition, the analysis of the effects of the consortium, particularly on exports, is done in isolation, not controlling for other factors that may affect exports and existing studies use very small samples. Therefore, future investigations in this area should seek to obtain larger samples in order to undertake a more rigorous empirical analysis. A deeper understanding of the benefits of export consortia can help policy-makers to design more appropriate export promotion policies.

\section{REFERENCES}

Antoldi, F., Cerrato, D., \& Depperu, D. (2011). Export consortia in developing countries: successful management of cooperation among SMEs. Berlin Heidelberg: Springer-Verlag.

Antoldi, F., Cerrato, D., \& Depperu, D. (2013). SMEs export consortia and the development of intangible resources. Journal of Small Business and Enterprise Development, 20(3), 567-583. doi.org/10.1108/JSBED-04-2013-0062

Bigliardi, B., Dormio A.I., \& Galati, F. (2011). Successful co-opetition strategy: evidence from an Italian Consortium. International Journal of Business, Management and Social Sciences, 2(4), 1-8.

Bilkey, W.J., \& Tesar, G. (1977). The export behavior of small-sized Wisconsin manufacturing firms. Journal of International Business Studies, 8 (1), 93-98. doi.org/10.1057/palgrave.jibs.8490783 
Brito, C., \& Silva, S.C. (2005). A methodological approach for the study of export grouping schemes, in 1st IIBC (Iberian International Business Conference), Porto, Portugal, 30th September- 1st October.

Criado, A.R., Carazo, P.C.M., \& Criado, J.R. (2005). El desarrollo exportador de las pymes industriales españolas participantes en un consorcio de exportación: un estudio de caso. Cuadernos de Gestión, 5(2), 95-116.

Das, T.K., \& Teng, B. (2000). A Resource-Based Theory of Strategic Alliances. Journal of Management, 26(1), 31-61. doi.org/10.1016/S0149-2063(99)00037-9

Espejo, A., Fuentes, F., \& Núñez, J. (2015). Los consorcios de exportación: revisión conceptual y factores determinantes de éxito. Revista de Estudios Empresariales, Segunda Época (2), 118144. doi.org/10.17561/ree.v0i2.2743

Ghauri, P., Lutz, C., \& Tesfom, G. (2003). Using networks to solve export-marketing problems of small- and medium-sized firms from developing countries. European Journal of Marketing, 37(5/6), 728-752. doi.org/10.1108/03090560310465125

Kogut, B. (1988). Joint ventures: theoretical and empirical perspectives. Strategic Management Journal, 9 (4), 319-332.

Leonidou, L.C. (2004). An Analysis of the barriers hindering small business export development. Journal of Small Business Management, 42(3), 279-302. doi.org/10.1111/j.1540-627X.2004.00112.x

Lima, G.B., Garcia, S.F.A., de Carvalho, D.T., \& Martinelli, D.P. (2007). Consórcios de Exportação no Brasil: Um Estudo Multi-Caso. FACEF Pesquisa-Desenvolvimento e Gestão, 10(2), 221-232.

O’Reilly, S., Haines, M., \& Arfini, F. (2003). Food SME networks: Process and governance - The case of Parma ham. Journal on Chain and Network Science, 3 (1), 21-32. doi.org/10.3920/JCNS2003.x027

Piñero, F.J., Herrera, G., \& Di Meglio, F. (2011). Los consorcios de exportación como estrategia de inserción internacional. Caso de Estudio: Grupo Asociativo de Productores de Maquinaria Agrícola (GAPMA), Provincia de Buenos Aires, Argentina. Revista Internacional de Desenvolvimento Local, 12(1), 9-18.

Renart, L.G. (1995). Consorcios de exportacion enfocados: El diseño y puesta en practica. Documento de Investigacion №289, IESE, Universidad de Navarra.

Renart, L.G. (1999). Consorcios de exportación y otros tipos de alianzas estratégicas entre empresas. Boletin Económico de ICE, 2627, 13-19 Septiembre.

SELA (2015). Export Consortiums: A strategic instrument for SMEs international insertion. Economic and Technical Cooperation, Regional Meeting on Export Consortiums, Mexico City, Mexico, 5 and 6 October 2015, SP/RRCE/DT N² 2-15.

Silva, S.C., \& Sousa, M. (2009). Consórcios internacionais de empresas de construção civil - o caso da Mota-Engil. Revista Portuguesa e Brasileira de Gestão, 8 (2), 51-63.

UNIDO (2003). Development of Clusters and Networks of SME's: the UNIDO programme. A Guide to Export Consortia. Vienna: United Nations Industrial Development Organization.

UNIDO (2009). The Strategic Management of Export Consortia: An analysis of the experience of UNIDO in Morocco, Peru, Tunisia and Uruguay. Vienna: United Nations Industrial Development Organization.

Welch, D., Welch, L., Wikinson, I.F., \& Young, L.C. (1996). Network analysis of a new export grouping scheme: The role of economic and non-economic relations. International Journal of Research in Marketing, 13 (5), 463-477. doi.org/10.1016/S0167-8116(96)00023-7

Wilkinson, I., Young, L., Welch, D., \& Welch, L. (1998). Dancing to success: export groups as dance parties and the implications for network development. Journal of Business and Industrial Marketing, 13(6), 492-510. doi.org/10.1108/08858629810246788 


\section{Authors}

The contribution share of authors is equal and amounted to $50 \%$ each of them.

\section{Rosa Forte}

Assistant Professor at the Faculty of Economics, University of Porto, and researcher at CEF.UP. She holds a PhD in Economics from the University of Porto.

Correspondence to: Prof. Rosa Forte, Faculty of Economics, University of Porto, Rua Dr. Roberto Frias, 4200-464 Porto, e-mail: rforte@fep.up.pt

ORCID (1) http://orcid.org/0000-0002-3441-9112

\section{Tiago Oliveira}

Holds a Msc in Economics from the University of Porto.

Correspondence to: e-mail: tiago.tafo@gmail.com

\section{Acknowledgements and Financial Disclosure}

The authors would like to thank the anonymous referees for their useful comments, which allowed to increase the value of this article.

\section{Copyright and License}

(c) (1) $\Theta$

This article is published under the terms of the Creative Commons

Attribution - NoDerivs (CC BY-ND 4.0) License

http://creativecommons.org/licenses/by-nd/4.0/

Published by the Centre for Strategic and International Entrepreneurship - Krakow, Poland

The journal is co-financed in the years $2019-2020$ by the Ministry of Sci- 
